[Sullivan, K. (2000). A Wolf in Sheep's Clothing: The Bulk Funding Debate. New Zealand Annual Review of Education, 9, 97-116]

\section{A Wolf in Sheep's Clothing: The Bulk Funding Debate}

\section{KEITH SULLIVAN}

\section{Abstract:}

This article examines the bulk funding debate and concludes, first, that it is the injection of extra money, rather than the mechanism of bulk funding itself, which has allowed some schools to enhance their offerings. Secondly, it argues that in having taken on the responsibilities of governorship (including becoming employers of their children's teachers), parents have been diverted from the more important role of engagement with their children's learning, in partnership with teachers. An historical overview of the vigorous debate over bulk funding is also provided, from its inception with Tomorrow's Schools up until the present, in view of its promised demise under current government policy. The article also presents a case study of a series of events at Colenso High School, Napier, where teachers, with support from the community, caused the Board of Trustees to reverse their decision to opt into bulk funding (the Fully Funded Option).

ince being elected in November 1999, the Labour/Alliance Coalition Government has indicated that, in line with its election manifesto, the bulk funding of teachers' salaries will be rescinded later this year. A select committee process has been initiated to canvas the issues before taking a final position, and those who wish to retain bulk funding are building a campaign in its favour.

One such case was made in an article in the New Zealand Herald of April 28, 2000. John Davies, Principal of Blockhouse Bay Primary School, Auckland, argues that four years of bulk funding in his school have produced substantial improvements in the quality of children's learning and in the school's educational programmes and systems. Through bulk funding the school has accumulated a current surplus of $\$ 120,000$ and has been able to improve its facilities and resources:
98 Keith Sullivan

- It has been able to release the two associate principals from their classroom duties in order to oversee curriculum development, to implement special English programmes for immigrants, to carry out an enrichment programme, to develop the school's new assessment requirements and to supervise 16 teacher aides.

- It has employed one extra teacher for senior and two for junior classes to improve teacher:pupil ratios.

- It has been able to release a senior teacher from regular duties to develop the school's information and communication technology interface.

- Full financial support has been provided for the school's reading recovery programme.

- It has been able to release senior teachers from other duties in order to provide professional development for junior teachers.

- It has employed three teacher aides to work with learning disability students in the senior classes.

- It has allocated $\$ 8000$ to support enrichment classes.

Davies is concerned with a claim from the Minister of Education (MOE) that when bulk funding is abandoned, 80 percent of schools will be better off. His fear is that his decile 8 school $^{1}$ (and other schools in the decile 7 to 10 range) will be amongst the 20 percent which will lose out, and that the school's current financial robustness will disappear as increased support is given to low decile schools. If Davies' report about the educational gains in his school is accurate, then there is a good argument for continuing to support such successes; however, others would argue that the bulk funding of teachers' salaries has wider implications which are to some extent disguised by the short-term gains of a financial windfall.

This article examines the long-standing and fraught bulk funding debate. First, I will trace the historical development of bulk funding from the Picot report (Department of Education, 1988) to the present day. Secondly, I will consider events early in 1999 at Colenso High School, Napier, when a hard-fought and sometimes bitter dispute took place between the Board of Trustees and the teachers over whether or not to adopt bulk funding. The Colenso case study provides a useful example of how the bulk funding debate has been played out in the public arena. Thirdly, I will discuss bulk funding in relation to broader politico-educational issues and draw some conclusions. 


\section{A Short History of Bulk Funding}

Under the leadership of Labour Prime Minister, David Lange, extreme ${ }^{2}$ changes occurred in the administration of education in New Zealand in the late 1980s. Central to these reforms was the concept of self-managing schools. ${ }^{3}$ In the Picot working party's report, the current system was described as having grown in an ad hoc and spasmodic fashion, consisting of complex and unhelpful processes enmeshed within layers of regional and central educational bureaucracies which were typified as inefficient, ineffective and unaccountable. In support of a change towards self-managing schools, the Picot report argued that in order for the administration of education to become more efficient, effective and accountable, decisions affecting schools are best decided where there is the most knowledge and will to make things work - in the schools themselves. Tomorrow's Schools (1988), the government response to the Picot Report, supported this change and described it as follows:

Institutions will be the "basic building block" of education administration, with control over their educational resources - to use as they determine, within overall guidelines for education set by the state. (p. 1)

Due to conflicting statements within the reform discourse, teachers were given a mixed message. On the one hand, reference was made to a recent OECD report that spoke very highly of New Zealand teachers. Also, the future running of schools was described as "a partnership between the professionals [the teachers] and the particular community in which it is located" (Tomorrow's Schools, 1988). On the other hand, teachers were characterised as interest groups who, through their access to decision-making, had inordinate (and by implication illegitimate) influence upon educational-policy making. Rather than this being seen as a useful meeting of minds between policy developers and professional practitioners, it was presented as "provider capture" to the detriment of "the consumer".

Central to effective self-management was the need to control school finances. This was to be implemented by each school receiving a budget in the form of a bulk grant, consisting of operational and teachers' salaries allocations:

1.3.5 While the bulk grant has two distinct components, the board has some decision in the use of these funds. It will have, for instance, some leeway in the numbers of teachers it will hire, and at what rate in the salary scale it will do so. The board may decide that an extra teacher is a priority, and may use funds from the operational grant to create another teaching position - or to subsidise two part-time positions. Similarly, it may decide that, given the objectives set out in its charter, it should forgo a teacher position and instead use funds to buy a computer or other high-technology teaching aids. (Tomorrow's Schools, p. 13)

The funds allocated to the school by government, then, could be spent at the school's own discretion. So on the one hand, it would be possible to use the operational budget for teaching purposes. On the other hand, if the school chose to increase the teacher:pupil ratio by spending money allocated for a teaching position on buying a computer, or on another high technology endeavour, it would be free to do so.

This situation appeared to loosen up the decision-making process so that schools could respond effectively to new developments and changing needs. While this may seem reasonable and possibly creative for Boards of Trustees, the implications for teachers of such a scheme could be regarded as threatening to their industrial rights and professional structures. ${ }^{4}$ For if Boards are able to replace good teachers with high-cost equipment, or with less experienced teachers, or to make staffing decisions at all, then it can be argued that teachers are in a very poor labour position, and are at the mercy of untrained amateurs (the parents on the Boards of Trustees).

The following excerpt from a 1994 interview with a Wellington principal, after several years of experience of the reforms, articulates some of these concerns. Since this interview was recorded, similar opinions about the consequences of bulk funding have become more widely held, particularly by teachers:

I don't think the relationship between principals and teachers has changed too much up to now, but I think it's going to change very quickly in the near future, especially if [the] bulk funding [of teachers' salaries] is imposed on schools. I think it could change then dramatically. Because then you're going to negotiate, maybe not immediately, but sooner or later the next step will be that you will have to negotiate your own 2, 3, 4 or 5-year contract with the Board of Trustees. And it will be the principal or the manager of the school that you will negotiate with rather than the shareholders. And if the school hasn't got the money, then you'll either lose a teacher or employ cheap teachers. And I think that would lead to conflict and certainly poor morale. Part of the professional structure is that there 
are professional steps in the ladder, and I think that would all just go by the board. There would be a lot of jealousy, a lot of in-fighting among staff, everybody would be watching to make sure that they are carrying out their job descriptions to the letter, if they're getting an extra $\$ 500$ a year more than this teacher or whatever. And that's the way the government wants to see it because it is in their plan.

Underlying this principal's prediction of what bulk funding would bring are several themes: that bulk funding would result in principals being re-framed as school managers rather than educational leaders; that competition would replace consensus and cooperation; that both principals and teachers would be subjected to contractualism and performance management processes, which would replace their current professional salary structures; that teachers' positions would be under threat; that decisions about staffing matters would be handled by non-professionals and non-teachers; and that this could lead to the breakdown of teacher/teacher and principal/teacher relations and result in low morale within teaching.

Following on from the Tomorrow's Schools recommendations, bulk funding was enacted into legislation (Education Act, 1989). Section 79 stated that bulk funding would cover schools' operational needs and teachers' salaries, although the implementation of the salaries component would be postponed so that procedures and requirements of the operational grant could be worked out first of all. Section 91 provided a provisional arrangement whereby the teachers' salaries component would not be paid to schools before December 1990. This was further extended (Education Amendment Act 1990, Section 22) until 31 December 1991 in order "to allow more time for research into a funding formula that was equitable, practicable and consistent with the principles of "Tomorrow's Schools'" (Butterworth \& Butterworth, 1998, p. 168). ${ }^{5}$

Towards the end of 1990, the National Party was elected to Government and Lockwood Smith became Minister of Education. One of the major issues to be resolved by Smith was the bulk funding of teachers' salaries. After in-depth discussions with the Ministry of Education CEO, Maris O'Rourke, Smith felt it was important to get on with the job of establishing bulk funding. However, because it was deemed politically unwise to isolate teachers and their unions at this time, he did not have support from either the Prime Minister or Cabinet (Butterworth \& Butterworth, 1998, p. 182). Further, recent research had indicated that there was little public pressure to extend schools' funding to include teachers' salaries. In fact, the second survey of the effects of the reforms, carried out by the New Zealand Council for Educational Research (Wylie, 1991), indicated a high degree of satisfaction from parents with the quality of their children's learning. Principals and trustees were positive about the autonomy the new arrangements brought, and only a few trustees wished to extend schools' autonomy further by establishing the bulk funding of teachers' salaries. Another issue was that, in light of recent public sector cuts following on from the financial crisis of the late $80 \mathrm{~s}$, teachers became even more convinced that a move to bulk funding would make their salaries vulnerable to cuts. Accordingly they hardened their position.

Although it may appear that the rush towards bulk funding had been halted in its tracks, during Lockwood Smith's tenure as Minister of Education (1990-96), several important changes took place that quietly created a strong foundation for an eventual full introduction of bulk funding. These were:

i Much of what was originally part of the teachers' salary grant was transferred to the operational grant, including items such as relieving teachers' payments. In 1992 the Education Act was amended so that the salaries of the principal and deputy were to be determined by contract and became part of the grant to the Board. As Butterworth \& Butterworth (1998) point out, "the percentage of funding allocated directly to schools rose from $6 \%$ in 1988 to $42 \%$ in 1993" (MOE, 1995, p. 30, cited in Butterworth \& Butterworth, 1998, p. 183). The only item that did not come to the Board as part of the school operating grant was teachers' salaries below the deputy principal level.

ii. Salary negotiations with teachers and their unions were transferred from the State Services Commission (which had dealt with public sector bargaining across the board) to the Ministry of Education (which placed contract negotiations within the Ministry's power base).

iii. A voluntary trial to evaluate the bulk funding of teachers' salaries (termed the Teachers Salaries Grant Scheme-TSG) was established which would formalise the basis for officially establishing bulk funding as a viable option for schools and create a structure upon which future schemes would be built.

Under TSG, schools that wished to take part would be bulk funded, based on a formula geared to average teachers' salaries. Under this 
formula, schools with a majority of young and inexperienced teachers (and therefore having to pay salaries at a rate largely below the average) would financially benefit, and those with higher paid and more experienced teachers would lose money (where salary costs exceeded the bulk grant). In July 1992, when applications to take part in the scheme closed, fewer than 3 percent of schools (55 to start with, increasing to 70 in 1993) had opted into the trial. This small number of takers was determined by:

i. the lack of financial advantage for most schools; and

ii. strong opposition from teachers and their unions.

The trial ran for four years and the process and its outcomes were monitored through the MOE's contract research arm (see Edwards, 1993 \& 1994, a \& b; Dixon \& Edwards, 1994; Hawke \& Hill, 1994 \& 1995).

The research found that, parallelling the experiences of Blockhouse Bay Primary School, the advantages accruing to schools were largely based on their having extra cash to use for supporting a wider resource base:

The reported benefits correlate highly with the use of funds. Increased staffing and the resulting lower pupil/teacher ratios and extra programmes for students were the most mentioned. (Hawke \& Hill, 1994, p. i)

Whereas NZCER's earlier findings indicated that few trustees supported extending bulk funding to teachers' salaries (and were therefore in line with teachers' thinking), the research found that this was not the case for participants in this scheme. In fact, the principals' and trustees' opinions on the matter seemed to diverge widely from those of the teachers:

Over $80 \%$ of principals and trustees believe that their schools are running more effectively and efficiently but $64 \%$ of the teachers do not feel there has been any improvement as a result of TSG. (Hawke \& Hill, 1994)

What was unclear, however, was whether this difference was just an artefact of the scheme (as it focused on schools which had opted into this bulk funding trial) or whether these differences reflected a wider trend and were indicative of a growing rift between teachers and trustees over this important issue.

In 1995, after the TSG trial had finished, the bulk funding of teachers' salaries became an option for all schools (the other option was to remain centrally resourced). In its now official form, the government re-named this version of bulk funding the Direct Resourcing of Teachers
Salaries Scheme (DRS). Funding for this scheme started in February 1996, and 63 of the 70 schools that had participated in the TSG trial chose to transfer to it. As an incentive to encourage schools to join DRS, extra financial support was given to directly resourced schools, with the reason given that there were extra administrative costs associated with the scheme. As a result of this subsidy, 80 percent of schools would benefit from or be unaffected by choosing to opt in. There appears to have been a gradual but significant response from Boards of Trustees to this initiative, as by early 1998, 12 percent of New Zealand schools had adopted the DRS scheme.

In May 1998, the National Government announced that it had allocated an extra $\$ 220$ million to the Education budget, with this money specifically earmarked for schools which chose to opt in to bulk funding. Clearly this was a strategy calculated to shift the balance further towards what they now called the Fully Funded Option (FFO). This new option offered that, for the first three years, the teachers' salaries bulk grant would be calculated as if all teachers in the school were at the top of their salary scale. This offer meant that spending surpluses for many schools that opted in could be substantial and that all schools would be in surplus to some extent. ${ }^{7}$ During 1999, the potential financial advantage was clearly proving too attractive for many Boards to turn down and there was a rush of schools to take up this option. There were also a significant number of disagreements between Boards and teachers, sometimes resulting in industrial action. For instance, standoffs at both Central Hawkes Bay College in Waipukerau and at Pakuranga College in Auckland had ended with the respective BOTs resigning en masse. In other instances, teachers unhappily accepted the consequences of their Board's decision.

Despite the level of anxiety and divisiveness this new scheme was creating, by 1 October 1999,824 schools $(31 \%$ of the 2,643 state and state integrated schools) had chosen to adopt the Fully Funded Option (ERO, 1999). ${ }^{8}$ Rumour had it that when a certain threshold had been reached, the Government would declare that all schools would become fully bulk funded.

\section{A Case Study: Colenso High School's Rejection of Bulk Funding What happened}

The case of Colenso High School attracted much attention and was well documented. A close examination of what expired there provides a 
useful exposé of the arguments and stances of the two sides to the debate. ${ }^{9}$

The events unfolded as follows. In early 1998, a new Board of Trustees was elected and, with full support and leadership from the school's principal, decided seriously to pursue the adoption of bulk funding in the form of the fully funded option. A meeting was held in October where teaching staff made clear their opposition and determination to resist bulk funding. The option was then discussed at the December Board Meeting, with a representative from the Ministry of Education presenting the case for the fully funded option, and the local regional Chair of the PPTA presenting the case against it. Seven members of Colenso's teaching staff attended this meeting.

Sensing that the Board was undecided about whether or not to adopt the FFO at their 10 February meeting, the teachers held a meeting and voted on this issue in order to convey formally their opposition to FFO to the Board before their meeting. Twenty-two of the 37 staff voted not to support the FFO. Nevertheless, the Board voted to adopt the direct resourcing of teachers' salaries.

As a result of this decision, the teachers called a strike for the following day (11 February) and pupils were sent home from school. On the evening of the strike, a meeting was held and the teachers informed the Board that:

i. they would be withdrawing their goodwill immediately (affecting sports, music and other activities); and

ii. that if and when a document was signed formalising the intention to adopt the FFO, they would give up their management units (and any extra salary this entailed)

In response to the teachers' stance, the Board did the following:

i. they closed the school on Friday 12 February on health and safety grounds in the school proper and because of a concern that the staff would not be supervising the playground areas; and

ii. they re-confirmed their decision to adopt the FFO but deferred signing the contract of agreement (which would legalise their decision).

On 16 February, senior students came out in public protest against both the Board's decision to adopt the FFO and the lack of student representation on the Board. On the following day the Parent's League held their AGM. They requested that the Board of Trustees re-consider their decision because it "had not consulted parents before it opted for bulk funding last week and most parents opposed the decision" (Daily Telegraph, 18 February, 1999, p. 2). The school's Whanau Group, which consisted of Maori parents, also met and decided to oppose the fully funded option.

In response, the Board met on 21 February and resolved to send information to parents about the Fully Funded Option. At this meeting, the Board also requested that staff re-instate their goodwill (which they did not agree to).

On 24 February a letter was sent out to parents from the Chair of the Board of Trustees with a package of information containing:

i. an outline of what had happened to date;

ii. a position statement from the Board; and

iii. a position statement from the teachers.

A request that parents send written responses by 5 March was made, as was an announcement that a meeting would be held on 3 March to clarify points for parents. At this meeting, most of the 85 people present expressed their opposition and the Board apologised for not having consulted the parents (Daily Telegraph, 4 March, 1999, p. 2).

So what were the arguments of the two sides in favour of and against the fully funded option of teachers' salaries? The following is an overview.

\section{The Board's perspective: In favour of the fully funded option}

The Board's arguments were centred around the financial advantages that the fully funded option would bring. They argued that it would enable the school to combat the academic and social barriers to learning experienced within this decile 3 school. Under a fully funded arrangement, they would receive approximately $\$ 300,000$ extra in their budget over a three-year period, including $\$ 120,000$ during the first year. ${ }^{10}$ The Board also stated that it would not use this money for buildings or equipment but to improve the quality of the school's programmes and to benefit the school's teachers through taking some of the pressure off them and supporting their professional development. The following specific intentions were stated:

- to employ more staff so as to attain better staff:student ratios;

- to employ extra staff to teach new and contemporary subjects, such as electronics; 
- to use relief staff so that permanent staff could run special programmes for students at risk, for extending high achievers, for leadership programmes and for overseeing academy groups in academic, sports and cultural areas;

- for bringing in specialists (craftspeople, artists, etc.) for short periods;

- to reimburse the expenses of sports coaches;

- to provide more and better staff development;

- to employ experts to provide outdoor programmes, etc.; and

- to provide staff with scholarships for advanced study or for examining good teaching practice in other schools.

The Board also argued that they intended to allow staff input into the use of the extra funding received and would consider putting some of the surplus aside for use in future years.

\section{The teachers' case against the fully funded option}

The following is a summary of the teachers' arguments:

i. that the National Government's commitment was to reduce spending and commitment in the state sector and that the fully funded option was, in effect, a long-term strategy for a reduction of education sector spending. They cited the government's record in respect of Health, the Fire Service and the Children, Young Persons and their Families Agency as examples of this trend in parallel areas. They also made reference to a communication from the State Services Commission to the Schools Consultative Group which indicated this and was also suggestive of a "conspiracy" component underlying the issue: "Bulk funding is one instrument which can break the link between wage rises and automatic additional salary funding";

ii. that the introduction of such a scheme would have disastrous effects on teacher recruitment and mobility;

iii. that the extra funding ( $\$ 304,000$ was the figure cited) was a bribe from government that was speculative and became larger when less experienced or even untrained teachers (read "cheaper") were hired by the school, and less when more experienced teachers (read "more expensive") were hired by the school. They implied that although in the short term more money would be available, it would have a negative long-term effect on education.
They then argued that MOE figures (1998) showed that 85 percent of teachers and 87 percent of schools were against FFO and that the teachers' professional organisation, the PPTA, and its 13,000 members opposed it. They referred to recent research into the salaries bulk funding trial and a major British study to argue that:

- "lower decile schools such as Colenso will be unable to compete and will become 'loser schools"';

- "FFO will mean the destruction of state funded education. As the bulk funding goes down, school fees charged to parents rise in order to maintain the services offered"; and that

- "FFO means that it will be individual Boards that have to negotiate salaries".

In relation to the case at hand, one in which cash was offered to the school, the teachers asked:

- "Why, if there is money available, can't the state schools get it anyway?";

- "Why is this money being offered to exclusive schools so that they can 'integrate' with the state?"11

- "Why, if the FFO is such a benefit, are $85 \%$ of us still opposed to it?";

- "Why does the school have to sign a binding contract that can only be changed after three years with the Minister's approval?"

They rounded out their case by stating that the teachers at their school had a combined 230 years of experience, that they opposed bulk funding to the extent that they withdrew their goodwill, and that they were prepared to give up management responsibilities that would cost the staff in question $\$ 95,000$ worth of their personal income per year.

They stated that they did not want to take this action but were totally committed to reversing the Board's decision, especially in light of its being made without consultation with parents, and being opposed by staff, the Whanau Group, the Parents League and senior students.

\section{The outcome}

Clearly, the Board had underestimated the depth of feeling against the fully funded option and the willingness of teachers, parents and students to turn their positions into direct action. In a letter to the parents and caregivers of Colenso High School dated 15 March, the 
Board of Trustees Chairperson stated that in relation to a request for comment to parents and caregivers, 67 responses had been received, 57 of which had rejected the fully funded option. He went on to state that at its meeting of 10 March, the Board of Trustees had reversed its position on this issue:

In view of the strongly opposing views within this Board, the Colenso School teaching profession, and the wider school community on the merits of the Fully Funded Option, this Board does not accept the Fully Funded Option for teachers' salaries.

He also announced the resignation of the Principal:

It is with great regret that we must inform you that Mrs Marilyn Scott advised the school today (Monday 15th) that she will be resigning from her position of Principal of Colenso High School. ${ }^{11}$

In an article entitled "Colenso U-turn appals Minister", a Ministry of Education adviser was quoted as saying that the Board was democratically entitled to make any decision without consulting the community.

\section{Discussion}

In examining the history of the bulk funding debate and the Colenso case study, I will focus on two issues:

- what the bulk funding debate has revealed about parents in their role as trustees; and

- the arguments that have been developed to justify the bulk funding of teachers' salaries.

"Are Boards of Trustees the appropriate mechanism for running our schools?" or "What should the role of parents be in the education of their children?"

By 1999, the bulk funding debate had been in existence for more than ten years and had been perceived widely by teachers as a real threat to their professional structures and their job security. The Colenso teachers, as well as trying to find an acceptable solution to the immediate situation, also took a stand based on a concern for the wider implications of the fully funded option. It is clear from their statement that they were politicised and strongly supported by their union, the PPTA.

The teachers felt that bulk funding (in the form of the fully funded option) would be harmful to their professional structures, that it heralded a regime that would put even more people off becoming teachers, and would place a major block in the way of job security, promotion and job mobility. With reference to parallel situations, such as in Health, they interpreted the fully funded option as "short-term gain for long-term pain", not only for them as teachers but also for their school.

On the other hand, the Board of Trustees at Colenso acted in a way that suggested a naive approach to a complex problem. Without getting a true sense of both the arguments and the strength of feeling of teachers, students and the wider community, they made a decision that they eventually had to back down on, with the added result that the principal of the school resigned. Their argument was similar to that of the principal of Blockhouse Bay Primary School and revolved around the immediate advantages that would be provided to the school through the resources available. The argument lacked depth and knowledge about the long-term implications.

In his "Opinion" in the New Zealand Education Review of 21 October 1988, O'Neill was more pointed in his assessment of such responses by schools, which he described as "greed dressed up as rational choice with a clear conscience". He cited the case of a Catholic secondary school where, although according to PPTA sources 93 percent of the teachers were opposed to bulk funding, the Board voted 8-4 in favour of adopting it. The principal of the school is reported to have said that "the ultimate responsibility of the Board was to do the best they could for the students."

Shortly after the Colenso incident, an article in the Daily Telegraph (12 March 1999) suggested that as a result of this bad experience for the Board, moves were afoot to make bulk funding compulsory, therefore preventing Boards from being put in such an untenable position. The head of the School Trustees Association was quoted as saying, "Imagine the effect the situation at Colenso has had on them. I feel sorry for them, constantly having threats hanging over their head."

Surely the arguments raised in the Colenso case are not about protecting Boards of Trustees from self-serving teachers but rather about whether or not most Boards have the ability effectively and sensibly to handle the important and often complex issues that are part of their brief. This is in no way meant to blame Boards in general, but to point out that in the Colenso situation, where a well-considered and fair decision needed to be made, the teachers had a better understanding of the local and wider issues and were better able to gauge the feeling of 
their community and to enlist its support. I would further argue that this resulted from their years of training and practical experience, as well as their general understanding as educational professionals. The Board, on the other hand, acted in an ill-informed fashion and made the following mistakes:

i. They did not use a proper and democratic process to get a consensus on this very important issue.

ii. As a result they did not represent the opinions of the school's parents who had elected them.

iii. They seemed either to have misjudged or dismissed the importance of this issue for the school's teachers and indeed seemed to lack understanding of the implications that the wholesale adoption of the option would have for education in New Zealand.

iv. They took an apparently immovable stance and then backed down.

In the first term of the Fourth Labour Government and just prior to the reforms, during Russell Marshall's stewardship as Minister of Education, a thorough process was undergone and The Curriculum Review (1987) was produced. One of the major intentions of the recommendations was to build a strong partnership between teachers and parents in the education of their children. This was swept under the carpet in 1988.

Problems have emerged more clearly now, and issues raised by teachers over the last decade are now having to be addressed. Have the parents of school children in fact been hijacked ("duped") into spending their time administering their children's schools, and being the employers of their children's teachers rather than being good parents and mentors of their children's learning? Is it fair that parents (as trustees) become pseudo "experts" who must take responsibility for decisions which prove to be wrong, in a situation where commonsense, intelligence and concern are not substitutes for training, professionalism and experience? In other words, is it right that parents as well-meaning citizens are handed the task of acting as managers when the education system has enough professionals of its own?

Was the Colenso incident just the tip of the iceberg? Should we not be more concerned about the abilities of untrained Boards of Trustees? Should we really place such unreasonable demands on parents?

It would arguably be more beneficial to have an educational partnership between parents and teachers that focuses on student's learning rather than on educational administration.

\section{Concluding Remarks}

The arguments that have been mounted in favour of bulk funding lack substance. Neither of the two recent reports about bulk funding (ERO, 1999; Wilson \& McAlevey, 1999) nor the earlier research convinces me that bulk funding is effective or that it has been properly assessed. In fact, the various studies echo the arguments of Colenso's Board and Blockhouse Bay Primary's principal. They are built upon an argument that under bulk funding in its various forms, school programmes and support of teachers' development have been enhanced. However, this is not proven. The truth is that it is the extra money that has been made available which has allowed these improvements to occur. Under a real bulk funding mechanism, the only way these extra offerings would come about would be because money would be saved from the teachers' salary budget. This would mean cutting back in a variety of ways, by hiring less experienced and cheaper teachers, not re-hiring older more experienced teachers, or (if it became permitted) to offer teachers a lower salary in order to keep their jobs - in effect, to downgrade the conditions of service of teachers. As Snook points out:

The decision taken by each Board of Trustees is crucial not just for the particular school but for the survival of the state system itself.

The decision is not a financial one but a moral one. (Snook, 1998, p.8)

The bulk funding of teachers' salaries was a lynchpin in the arsenal of the New Right which, along with various other mechanisms such as imposed professional standards and performance management, were designed to exercise more control over teachers' work. ${ }^{13}$ With a select committee process now underway, the fate of bulk funding appears almost to be sealed. But amongst the select committee's members are one ACT and two National Party representatives. These two political parties are fully supportive of bulk funding, with National commitment so strong that they have been placing full page advertisements to this effect in the nation's newspapers. The Bulk Funded Schools Association is similarly vociferous in its campaign to gain support for the retention of bulk funding. There are apparently justifiable fears afoot that if enough pressure is brought to bear in the political arena, a compromise will be brokered whereby bulk funding will be thrown out in name only and be replaced by something else so loose that bulk funding will again make its entrance, albeit by the back door.

Such tactics are not new. For instance, previous National Governments have tried to take the heat out of the bulk funding debate 
by altering the terminology used to describe bulk funding. Lockwood Smith referred to his experiment as the Teachers Salaries Grant Scheme. It was then called the Direct Resourcing of Teachers Salaries Scheme, and most recently was termed the Fully Funded Option. I believe the Government needs to stand firm on its stance over bulk funding. A wolf may dress up in sheep's clothing, so we must not deceive ourselves by believing that under the clothing there is anything hiding but a wolf. Teachers have not allowed themselves to be deceived by such manoevures, although it could be argued that a large number of Boards of Trustees have.

Bulk funding has been presented as a flexible approach that has created benefits for schools that have experienced it. The truth is, however, that in the long run when the bulk fund is reduced, as has happened in the university sector, then the quality of education comes under threat and the conditions of teaching staff are undermined. I would argue that bulk funding of teacher salaries in whatever form is harmful, and I believe that the evidence is there to support that contention.

\section{Notes}

1. In New Zealand, schools are categorised in a decile fashion against a set of criteria related to SES and ethnicity, with decile 1 schools seen as the most disadvantaged and decile 10 the most advantaged. See Fiske \& Ladd (2000, pp. 79-82) for a useful explanation of this. Rating schools in such a fashion has meant that those with lower decile ratings are generally in the position to receive more financial support for a range of programmes to help improve their performance.

2. I have purposely used the word "extreme" rather than "radical", which is often used to describe the reforms. My definition of radical change is change rooted in a concern for the revision of the status quo in favour of equal opportunity and social justice.

3. For an understanding of some of the concepts behind self-managing schools, see Caldwell \& Spinks, 1988.

4. In the national context, this sort of industrial relations parry was being formed in a general way with the development of the Employment Contracts Act, which was intended to undermine the strength of collective bargaining by the various sectoral unions.

5. As with the schools sector, kindergartens, colleges of education and polytechnics were similarly targeted for full bulk funding in Tomorrow's Schools and now exist under such an arrangement. There were, and still remain, major concerns about the effects of this on kindergartens. The
MOE monitored this process for kindergartens and has produced several reports. See Wilson, Houghton \& Piper (1996), Wilson \& Houghton (1995), and Houghton \& Wilson (1993).

6. NZCER's 1996 survey of the effects of the educational reforms found that $14 \%$ of school trustees surveyed "thought that their schools should be bulk funded, or that each school board should have the responsibility for negotiating salaries and employment conditions with its teaching staff" (Wylie, 1997, p. 136).

7. If schools opted in to FFO, they had to agree to stay in it for three years. At the end of this period (with the agreement of the Minister of Education), they could choose to leave the scheme but they would then be liable for any contractual settlements made at higher rates than agreed to in the collective employment contract or for the costs of any full-time staff extra to the school's entitlement.

8. Wylie's (1999) study carried out a few months earlier than the ERO's showed $26 \%$ of schools had chosen the FFO option. Statistically, this was shown to include $32 \%$ of urban schools, $18 \%$ of rural schools, $54 \%$ of provincial schools (small in number) and $44 \%$ of schools with rolls over 300

9. The information presented here is based on publicly disseminated information from the Board of Trustees, newspaper articles and discussion with informants familiar with the situation.

10. With teachers' salaries increasing each year, this would mean a slight drop in schools' surplus due to increased salary expenditure; however, the government assured schools that any increases in salary costs due to any collective employment contract award would be factored in so that schools would not lose any income due to such settlements.

11. This statement was made in reference to three local private schools that had recently integrated. They were: Iona College, Lindisfarne College and Woodford House.

12 After the bulk funding affair, two members of the Board resigned, but the rest of the Board remained and by all accounts are working well with the school.

13. See Sullivan (1999) for an examination of these issues.

\section{References}

Butterworth, G., \& Butterworth, S. (1998). Reforming education: The New Zealand experience 1984-96. Palmerston North: Dunmore Press and Wellington: Ministry of Education.

Caldwell, B. J., \& Spinks, J. M. (1988). The self-managing school. London: Falmer Press. 
Davies, J. (2000, April 28). How one school will suffer with no bulk-funding. New Zealand Herald, p. A13.

Department of Education. (1987). Curriculum review: Report of the committee to review the curriculum for schools. Wellington: Government Print.

Department of Education. (1988). Administering for excellence: Effective administration in Education (The Picot report). Wellington: Government Print.

Department of Education. (1988). Tomorrow's schools: The reform of educational administration in New Zealand. Wellington: Government Print.

Dixon, K., \& Edwards, W. (1994). The financial picture emerging from schools in the teacher salaries grant scheme trial: A preliminary study based on the first year. Palmerston North: Massey University, ERDC.

Education Review Office. (1999). Good practice in managing the fully funded option. Wellington: Education Review Office.

Edwards, W. L. (1993). Evaluation of teacher salaries grant scheme trial: First interim report, early experiences. Palmerston North: Massey University, ERDC.

Edwards, W. L. (1994a). Evaluation of teacher salaries grant scheme trial: Second interim report, the second year. Palmerston North: Massey University, ERDC.

Edwards, W. L. (1994b). Evaluation of teacher salaries grant scheme trial: The trial in action, case studies in year one. Palmerston North: Massey University, ERDC.

Fiske, E. B., \& Ladd, H. F. (2000). When schools compete: A cautionary tale. Washington, D.C.: Brookings Institution Press.

Haines. L. (1999, February 18). Colenso parents urge board to reconsider. Daily Telegraph.

Haines, L. (1999, March 4). Board to reconsider bulk-funding choice. Daily Telegraph, p. 2.

Haines, L. (1999, March 12). Disputes forcing compulsory stand. Daily Telegraph.

Hawke, K., \& Hill, J. (1994). Evaluation of teacher salaries grant scheme trial: The third year. Palmerston North: Massey University, ERDC.

Hawke, K., \& Hill, J. (1995). Evaluation of teacher salaries grant scheme trial: The fourth year. Palmerston North: Massey University, ERDC.

Houghton, R. M., \& Wilson, A. G. (1993). The introduction of bulk funding, including salaries, of kindergartens: Establishment of 1992 baseline for monitoring report to the advisory committee. Dunedin: University of Otago Consulting Group.

Ministry of Education. (1995). New Zealand schools: 1994. Wellington: Ministry of Education

Ministry of Education. (1999). A survey of directly resourced (bulk funded) schools. Wellington: Research Division, Ministry of Education.

Organisation for Economic Cooperation and Development. (1983). Review of national policies for education: New Zealand. Paris: OECD.

O'Neill, J. (1998, October 21). Opinion: Greed with a clear conscience. New Zealand Education Review, p. 6.

Snook, I. (1998). Bulk funding: On the agenda again. Unpublished paper.

Sullivan, K. (1999). Teacher standards and professionalism: Contested perspectives in a decade of reform. New Zealand Journal of Educational Studies Special Issue: A Decade of Reform in New Zealand Education: Where to Now?, 34(1), 144-155.

Wilson, A. G., \& Houghton, R. M. (1995). The introduction of bulk funding, including salaries, of kindergartens: Financial and operational impacts for 1993 and 1994. Report to the advisory committee. Dunedin: University of Otago Consulting Group.

Wilson, A. G., Houghton, R. M., \& Piper, R. K. (1996). The introduction of bulk funding, including salaries, of kindergartens: Financial and operational impacts for 1992 to 1995. Report to the advisory committee. Dunedin: University of Otago Consulting Group.

Wilson, A. G., \& McAlevey, L. G. (1999). Do directly resourced schools differ? A comparison of resource allocation patterns and strategies in directly resourced and centrally resourced schools. Dunedin: University of Otago Consulting Group and Wellington: Research Division, Ministry of Education.

Wylie, C. (1991). The impact of Tomorrow's Schools in primary schools and intermediates: 1990 survey report. Wellington: New Zealand Council for Educational Research.

Wylie, C. (1997). Self-managing schools seven years on: What have we learnt? Wellington: New Zealand Council for Educational Research.

Wylie, C. (1999). Ten years on: How schools view educational reform. Wellington: New Zealand Council for Educational Research

\section{The author}

Keith Sullivan is a Senior Lecturer in the School of Education at Victoria University of Wellington. His Email address is:

Keith.Sullivan@vuw.ac.nz. 